\title{
Development of tourism in Polish poviats in the years 2010-2017
}

\author{
Jerzy Korzeniewski ${ }^{1}$ (D) Maciej Kozłowski ${ }^{1}$ (D)
}

Published online: 7 August 2019

(c) The Author(s) 2019

\begin{abstract}
Poland is divided into 380 poviats. However the statistical data on the development of these small regions is available from official statistics, there is no study known to the authors which has analysed the mutual dependencies between the tourist development of poviats (understood either as the historic rate of development or the current state of development) and their natural potential for development. Moreover, the research and data available are not coherent methodologically because they are based on single indicators or variables. Authors' study seeks to be more general because it combines popular tourist development indicators. The basic goals are twofold: (1) use multivariate tourist data to assess the development of all poviats; (2) compare this assessment with the tourist attractiveness of poviats. To this end, widely applied and well-known indicators of tourism and development are used, such as Charvat's index and Schneider's index. Statistical tools used are graphs and correlation analysis.
\end{abstract}

Keywords Tourist functions $\cdot$ Poviats $\cdot$ Tourist development

\section{Introduction}

There is no doubt a growing awareness of the importance of tourism to regional development and sustainable development. The phenomenon of tourism is one particularly complex. It has, by virtue of its activity, implications in the social, political, cultural and economic areas of activity. The sheer volume and complexity of the offer of tourist services have led to the development of travel and tourism industries. Because of this, the phenomenon of tourism should be regarded as a separate branch of the economy. This branch of the economy is closely linked with the development levels and growth of the other branches of the economy (Bunghez 2016). The wide range of activities included in the category of tourism makes this industry an important link connecting various areas of the economy as well as societes. The tourism potential is determined by the sum of all resources (natural,

Maciej Kozłowski

maciej.kozlowski@uni.lodz.pl

Jerzy Korzeniewski

jerzy.korzeniewski@uni.lodz.pl

$1 \quad$ University of Lodz, Lodz, Poland 
human, cultural, historical, infrastructure) which, in turn, constitutes in a tourist offer (Heath and Wall 1992).

Thanks to tourism, more developed European countries perform a high share in GDP (Gburova et al. 2015). Travel and Tourism as one of the world's largest economic sectors, generates $10.4 \%$ of world GDP (WTTC 2019). Tourism can support the economic development of both local community and the economy of a country, through earnings from domestic or foreign visitors. The direct economic contribution of travel and tourism amounted to approximately 2.57 trillion U.S. dollars in 2017. The travel and tourism industry is one of the world's largest industries with a global economic contribution (direct, indirect and induced) of over 8.27 trillion U.S. dollars in 2017. In 2017, international tourism revenue amounted to 1.34 trillion U.S. dollars (Statista 2019).

\section{Tourism and its role in poviats development: literature's review}

In the Lisbon Strategy, tourism as an important factor of regional policy was identified as one of the priorities of the EU cohesion policy for 2007-2013, both in terms of convergence and territorial cooperation. The importance of tourism has also not been neglected in the current regional policy of the EU and Poland. In 2010, the National Strategy for Regional Development of 2010-2020: Regions, Cities, Rural areas was adopted (Hącia 2012). The aim, among others, was to identify areas which require additional financial outlays that should result in improved territorial cohesion and increased tourism competitiveness of regions, including poviats. ${ }^{1}$ Poviats were appointed to living in Poland in 1998 as a result of the reform of public administration (Act of 24.07.1998 on the Introduction of a Three-level Territorial Division of the State and Act of 05.06.1998 on Poviat Self-Government). ${ }^{2}$ As of 2018, there were 380 poviat-level entities: 314 land counties, and 66 city counties. A poviat comprises several gminas (communes). Even poviats have very small budgets and low expenditure competencies, it plays an important role in fulfilling the tasks related to the following areas: education, health care, social welfare, culture, tourism and public transport, spatial development, water management and environmental protection. The tasks of the poviats can be included in the so-called social infrastructure.

Given the unanimity that development of tourism increases the competitiveness of a regional industry (in this case-poviats') (Porter 2002; Rocha 2004) and given that tourism is a powerful instrument for regional development (Engelstoft et al. 2006), it is relevant and crucial to discuss and to analyze the tourist attractiveness of poviats. Similar research has been conducted (although in different areas, aspects and concepts ${ }^{3}$ ) by many scientists and researchers in different parts of the world, i.e. in New Zeeland (Cameron et al. 2001), South Africa (Meyer and Meyer 2015), Romania (Bunghez 2016), so it is impossible to list all, but all of them try to evaluate the relative importance of tourism in territorial units.

\footnotetext{
1 Unfortunately, in many cases the actions taken are not very effective, which results from the passive attitude of local authorities, which leads in turn to a lack of promotional activities and the lack of use of their assets.

2 A poviat (powiat) is the second-level unit of local government and administration in Poland, equivalent to a county, poviat or prefecture in other countries. The term "poviat" is most often translated into English as "county" or "poviat". A poviat is part of a larger unit, the voivodeship (Polish województwo) or province. A poviat is usually subdivided into gminas (in English, often referred to as "communes" or "municipalities").

3 These concepts are also related to the clusters, in particular tourism, according to several researchers' visions (see: Santos Estêvão and Ferreira 2009).
} 
"Tourism" means organized or individual trips away from home for sightseeing purposes or as a form of active recreation, while "recreation" commonly means rest, relaxation, and entertainment (Kurek 2007). The other definition concludes that "Tourism is the study of man (the tourist) away from his usual habitat, of the touristic apparatus and networks, and of the ordinary (non-tourism) and nonordinary (tourism) worlds and their dialectic relationship" (Jafari 1987).

It is difficult to give a clear definition or interpretation of the concept of tourism, which results from dynamic and quite complex changes in the natural environment and the whole macroeconomic environment. The World Tourism Organization gives the following notion of tourism (http://www.tugberkugurlu...): it is all the activities of persons who travel and stay for leisure, business, or other purposes not longer than a year uninterruptedly outside their daily environment.

In general, the definition of tourism focuses on the movement of persons (travelling), the duration of change in the place of residence, and on specific tourism purposes. As this is a market category, it can be attributed to functions of demand (tourism) and supply (sphere of tourism services based on material and organizational measures, which form the tourism economy in its broadest sense) (Seweryn 2010). Another definition is given by J. K. Walton (Encyclopedia Britannica 2019): "tourism-the act and process of spending time away from home in pursuit of recreation, relaxation, and pleasure, while making use of the commercial provision of services".

As pointed out by Cudowska-Sojko (2011), "the whole tourism economy is heterogeneous and complementary in nature. Entities operating in the region can be divided into the following groups: enterprises in the strict sense of tourism (carriers, travel agencies, hoteliers, catering), entities focused on tourism (souvenirs, tourist and sports equipment), and entities indirectly dependent on tourism demand (providing financial services, marketing, agriculture, etc.). The demand of tourists is also complex, but also diversified, and rich in terms of travel motives and forms of tourism activity undertaken by tourists in the region. Each of the tourists has an impact on the tourist supply, and the 'product' is 'adapted to the needs of the consumer'. These conditions contribute to the fact that tourist supply is dispersed (an example is diversity of accommodation facilities). Temporary fluctuations in demand and inflexibility of supply make the tourism economy unstable and risky. The tourism economy is strongly influenced by the global nature of demand". Tourists are therefore witnessing processes of "production of a regional tourism product" (Kruczek and Zmyślony 2010).

As it is known, tourism is an important factor of social and economic development, and the size, structure, and dynamics of incoming tourist traffic influence the development of economic activity aimed to its adoption. Tourism is also seen as a regional development tool to assist in the creation of new local economic activities (Richardson 2010). Tourism has proven to be an effective sector for economic growth allowing for the diversification of a local economy, attracting foreign exchange investment which could lead to the improvement of the balance of payments, regional development, creation of employment and income and also the stimulation of domestic household consumption (Modeste 1995; Creaco and Querini 2003; Steiner 2006).

Greater tourist traffic results in stronger development of tourist functions in the region (Hacia 2010). However, this development is not possible without specific actions (Gołembski 2009): improvement of transport accessibility; improvement of road transport infrastructure (Banasik 2014); application of specific incentives for the use of rail transport, organized coach, and bus journeys; promotional actions leading to an increase in foreign incoming tourism; increasing the number of foreign and domestic air connections, etc. 
It is also necessary to expand and modernize the accommodation base and to implement measures aimed to better use this base, especially during the off-season. Undoubtedly, the development of tourist traffic is influenced by gastronomic base, the expansion of which may significantly extend the tourist season.

Significant importance should also be attached to the range of accommodations available for business travellers, and thus the construction of hotels of a higher standard with the possibility of organizing conferences (conference centres). Active and specialist tourism is also very popular, which requires further actions to increase the density of bicycle paths and hiking trails. At the same time, educational offerings become indispensable for individuals involved in tourism services for a given area; such education must include tourism economics, service marketing, and tourism geography.

The complexity of conditions and thus adjustment measures imposes on local authorities the necessity of creating and updating the strategy of tourism development with the use of external financial resources and specific regional resources, including poviat ones. The strategic objectives (social, economic, and spatial) must also be accepted by the local community (Zalech 2010).

Article 4 of the Polish Act on County Self-Government states that the self-government performs public tasks defined by acts of supra-municipal nature in the following areas: physical culture and tourism, counteracting unemployment and activation of the local labour market, and poviat promotion (Act on County Self-Government 1998); this clearly indicates that it is necessary to conduct activities aimed to develop tourism, which is probably one of the most interdisciplinary branches of the economy. The poviat's most important tourism-related tasks are as follows (Borzyszkowski and Marczak 2010): running institutions of physical culture, tourism and recreation; registration and supervision over activities, as well as co-financing of associations operating in the fields of sports and tourism; financial support for tourism events ${ }^{4}$ and so on.

Conducted activities should have a long-term character and use various tools depending on the degree and dynamics of development of individual poviats, as well as on the current system of society values and their preferences (Rudnicki 2010), which over several years will contribute to a faster development of tourism, and thus activate the local market and increase the prosperity of residents (Kurek 2008). These processes and activities, combined with the development of material and organizational bases (e.g. institutions), will improve the competitiveness of a given poviat in comparison to others. However, the measures alone are not sufficient without taking into account local tourist attractions, which include landscape, climate, traditions, folklore, museums, way of life, etc. (Gołembski 1998). Everything is of key importance in the growth of tourist traffic and demand for services (e.g. accommodation). The multifaceted importance of tourism and tourist traffic makes it difficult to measure and unambiguously assess them (Table 1).

The demand reported by tourists for a product is reflected in their expenditure, which becomes the revenue of entities meeting the given needs, and which in turn is spent on salaries of people working in tourism services and other activities, thus increasing budget revenues, including tax revenues. The impact of tourism on employment growth is rather indisputable: broadly understood tourist demand and its growth increases activity and employment in the field of tourism services and also influences changes in the professional

\footnotetext{
4 Organization of such sports events helps poviats in acquisition of new tourist, sports, and general infrastructure facilities, which is undoubtedly a source of social, cultural, and economic benefits (complementarity of tourism and sport development); cf. (Hadzik 2010).
} 
Table 1 Impact of tourism on the local economy. Source: Kruczek and Zmyślony (2010)

\begin{tabular}{|c|c|}
\hline Positive impact & Negative impact \\
\hline Cash inflow & Price increases \\
\hline $\begin{array}{l}\text { Increase in employment and development of entrepre- } \\
\text { neurship }\end{array}$ & $\begin{array}{l}\text { Hindering the development of other types of eco- } \\
\text { nomic activity (alternative development costs) }\end{array}$ \\
\hline Stimulation of investments and capital inflow & $\begin{array}{l}\text { Overinvestment, infrastructure congestion, com- } \\
\text { mercialization }\end{array}$ \\
\hline $\begin{array}{l}\text { Development of technical, communications, and social } \\
\text { infrastructure }\end{array}$ & Risk of dependent development \\
\hline Attractive image of the region & \\
\hline
\end{tabular}

structure of local population, from production to services. This is connected with necessary additional investments, inflow of capital, development of infrastructure, construction of hotels, etc., which results in an increase in the attractiveness of a region or poviat. Despite these advantages, there are also some shortcomings resulting from excessive development of tourism (overtourism ${ }^{5}$ ), which should be regarded as a harmful phenomenon, especially for the local community, as it contributes, among others, to an increase in prices, often overinvestment, and decrease in care for other areas of poviat development, which in the long run may adversely affect the dynamics of tourist traffic. ${ }^{6}$

It seems that poviats, like regions, can be classified according to several criteria used in tourism (Kruczek and Zmyślony 2010):

- type of natural environment (coastal poviats, mountain poviats);

- type of cultural environment (poviats of sightseeing and pilgrimage tourism);

- geographical location;

- size (mass and alternative tourism);

- organization of tourism (organized and non-organized tourism);

- method of using the natural environment (canoe tourism, winter sports);

- tourism type (specialized, multifunctional);

- location in relation to tourist traffic emissions (metropolitan, peripheral).

Another classification given by Glăvan (2006) is based on the enumeration the natural elements (natural resources) that can attract tourists and, therefore, can be transformed into tourism products. The classification of tourism resources facilitates the elaboration of a typology of tourism types, its necessity resulting from "the applicative side of the geography of tourism, from practice, which imposes the realization of scientific studies of the typical features, of the relations between the types of tourism phenomena" (Swizewski and Oancea 1977). The classification of territorial units given by Bulai and Cehan (2015)

\footnotetext{
${ }^{5}$ In short, overtourism occurs when there are too many visitors to a particular destination. "Too many" is a subjective term, of course, but it is defined in each destination by local residents, hosts, business owners, and tourists. When rent prices push out local tenants to make way for holiday rentals, that is overtourism. When narrow roads become jammed with tourist vehicles, that is overtourism. When wildlife is scared away, when tourists cannot view landmarks because of the crowds, when fragile environments become degraded-these are all signs of overtourism; (Francis 2019).

6 More information on this subject is written by Butowski (2009).
} 


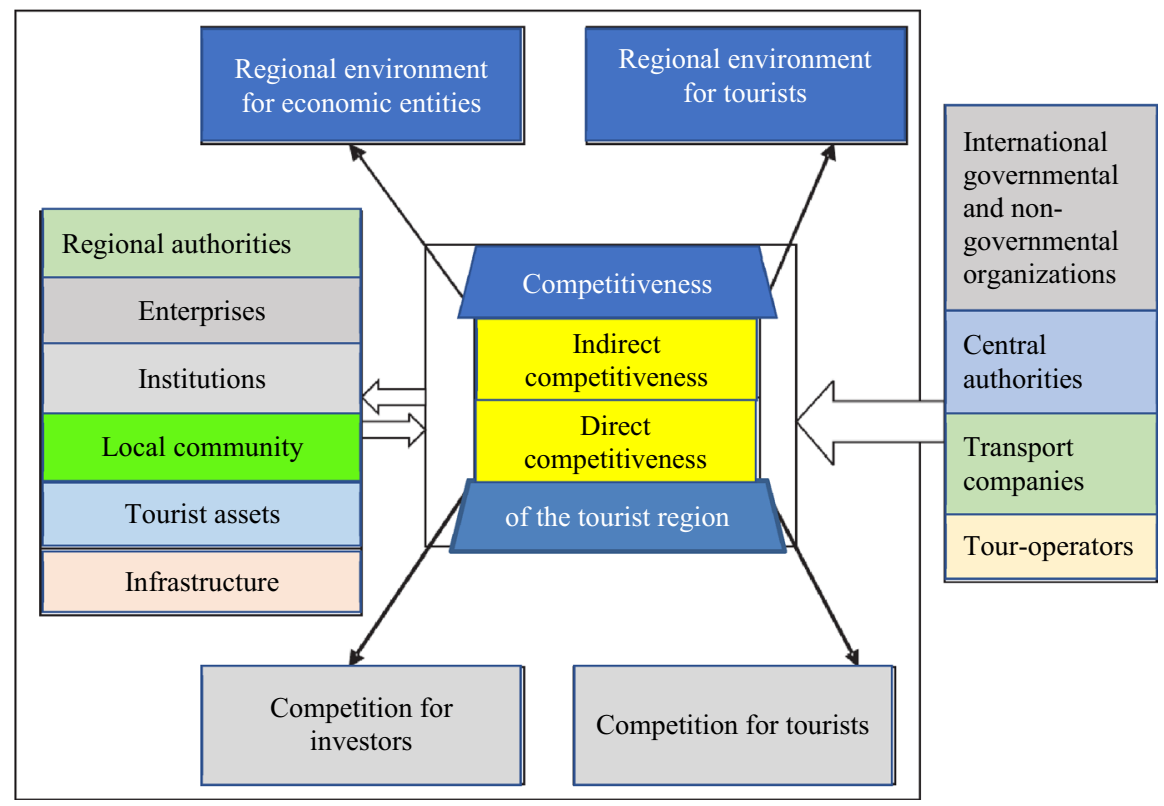

Fig. 1 Factors of tourist competitiveness of the poviat. Source: Nawrot and Zmyślony (2009)

distinguishes natural resources, cultural resources, tourism infrastructure, technical infrastructure, arrivals and overnights, as a premise for tourism development.

Due to these criteria and thus the diversity of counties or poviats, it is necessary to take a holistic approach to their development, but also in some sense this approach has to be individualized, precisely because of their specificity. This is where we come to the notion of regional or local development programming. Development programming can be understood as a set of specific activities and actions at the level of regional or local strategies, which aim to bring territorial units onto the path of sustainable development (Nawrot and Zmyślony 2009). In the case of the county and local sources of competitiveness, the tools and methods used in microeconomics are applied, especially in relation to the theory of competition and enterprise development (cf. Jakubowska et al. 2008; Słodowa-Hełpa 2002). Due to the openness of the macroeconomic environment, the local competitiveness (poviat) moves to the international level, which gives this local government unit the dimension of an international tourist entity and which, when treated in this way, requires the complexity and control of structured actions (Poon 1993). Conducting such activities aimed to increase competitiveness ${ }^{7}$ at the local level (but not only), and not only in the area of resources but also in the area of so-called soft factors related to the institutional and social environment [cultural, ethical, religious (Dołęgowski 2002)] is the main element of local development strategies. These strategies are ultimately intended to support the local community and its values (Winiarski 1999). Competition for tourism is mainly direct (Rapacz 2004), which means competition between poviats for various types of benefits, including income and jobs, through competition for access to financial resources, investors, location of government agencies, and major tourist events (Jędrzejczyk 2003). At the same

7 Competitiveness means the ability to act in competitive conditions; (Godlewska and Typa 2002). 
time, it should be remembered that the competitiveness of poviats depends on the broadly understood macroeconomic environment (Fig. 1).

As can be seen, the complexity of factors influencing local competitiveness in the context of competition for attracting tourists imposes on local authorities the necessity of undertaking comprehensive management activities. The effects of this management can be reduced to the development of tourist functions of the poviat.

\section{Measurement of tourist functions of the poviat: general presentation}

Tourism as a whole cannot be measured due to its complex nature, the multitude of activities it comprises, or the inability to measure trade flows resulting from the sale of goods and services consumed by tourists and the turnover that could be achieved if there were no tourist traffic (Szromek 2013). Obviously, it is possible to measure the number of tourists, the number of overnight stays, the number of accommodation places, etc. However, this still needs to be combined with some reference measures, e.g. the studied area or number of inhabitants of a given region/poviat. It is possible to talk about the level of development of the tourism function of a given area-usually a municipality, county, or region-and to analyse or measure this development. The tourist (recreation) function of an area is in turn a broadly understood as a social and economic activity performed by a specific area (region or locality) and its inhabitants in order to restore the normal psychophysical abilities of their organism to visitors as a result of fatigue, using the natural properties of the geographical environment (Matczak 1982). In a broad sense, the tourism function refers to activities related to the provision of tourist services in a given area meeting the abovementioned conditions. However, there are several measures of the tourism function which are not always compatible, i.e. the area has ambiguous assessments by means of different indicators (Szromek 2013), hence the need for a synthetic indicator, the so-called twodimensional indicator of tourism function or logistical indicator of the tourism function (Szromek 2012). The most popular measures of the tourist function include (Chudy-Hyski $2006)^{8}$ :

- Baretje-Defert's indicator (tourist function index of the town), expressed in terms of the number of tourist accommodation places per 100 permanent residents,

$$
W_{B D}=\frac{\text { number of tourist accommodation establishments }}{\text { number of permanent residents of thearea }} \times 100
$$

- Defert's indicator (tourism function index), expressed in terms of the number of tourists staying overnight per $1 \mathrm{~km}^{2}$ of the area'

\footnotetext{
8 The first one who applied this type of research was French geographer Pierre Defert, who created the tourist function index in 1967. In the literature, this index is usually termed as Defert's index. In 1978, French explorer Rene Baretje improved existing Defert's index and brought it into relation with the spatial unit of destination area; (Marković et al. 2017).

${ }^{9}$ Defert's index T(f) is also presented as measuring the intensity of tourism within specific destination on the basis of the following formula: $D T F I=T(f)=N x 100 / P$, where DTFI $=T(f)$ is Defert's tourist function index, $\mathrm{N}$ is the number of beds and $\mathrm{P}$ is the number of local residents; (Marković et al. 2017).
} 


$$
W_{D}=\frac{\text { number of tourists using overnight accommodation }}{\text { area in } \mathrm{km}^{2}} \times 100
$$

Numerous studies, in addition to Defert-Baretje's index, also included other indicators for the measurement of tourism intensity. One of them, often used in studies, is Charvat's index. Thus, Polish researchers used Charvat's index to demonstrate the intensity of tourism development as a consequence of urbanization (Marković et al. 2017):

- Charvat's indicator (tourist accommodation saturation index), expressed as the number of overnight stays per 100 inhabitants of the area (per $1 \mathrm{~km}^{2}$ of total area),

$$
W_{C h}=\frac{\text { number of overnight stays }}{\text { number of permanent residents of the area }} \times 100
$$

- Schneider's indicator (tourism traffic intensity index, intensity of tourist saturation), expressed as the number of tourists staying overnight per 100 inhabitants of the area (Treija and Skujeniece 2015):

$$
W_{S c h}=\frac{\text { number of tourists using overnight accommodation }}{\text { number of permanent residents of the area }} \times 100
$$

- density index of the accommodation facilities, expressed in terms of the number of establishments offered to tourists per $1 \mathrm{~km}^{2}$ of area,

$$
W_{G B N}=\frac{\text { number of tourist accommodation establishments }}{\text { area in } \mathrm{km}^{2}}
$$

In addition, the Schneider and Defert indicators refer to the intensity of tourist traffic, and the $\mathrm{W}_{\mathrm{BD}}$ and $\mathrm{W}_{\mathrm{GBN}}$ indicators refer to the level of tourist development, so they represent both demand and supply site.

In world literature on tourism and the tourist function, measures of tourist attractiveness are also used, which are widely applied in the comprehensive evaluation of tourist values of poviats or counties (Cugno et al. 2012; Gismondi and Russo 2004). These measures include ${ }^{10}$ the cultural attractiveness index (WAK), environmental attractiveness index (WAS), business and hotel attractiveness index (WAB), and tourism attractiveness index (WAT). ${ }^{11}$

The cultural attractiveness index (WAK) is a weighted sum (weights are given in brackets) of eight components (Fig. 2).

WZW, WZO, WZX, WPI, WMW, and WUI indicators were calculated according to the formula

$$
W s k=100 * \frac{W_{p}}{W_{\max }}
$$

\footnotetext{
${ }^{10}$ All the information contained in this part comes from an experimental study based on statistical data from (among others) accommodation, culture, and national heritage, as well as natural protected areas, entitled Analysis of tourist values of poviat and their immediate surroundings (Central Statistical Office 2017).

11 All weights were determined by an experimental method of experts by a team consisting of statisticians and other researchers in the subject matter discussed. The weights assigned in all formulas and diagrams result from the assessment of the importance of individual indicators for tourist attractiveness; an information obtained from the head of Central Statistical Office, 09.05.2019.
} 


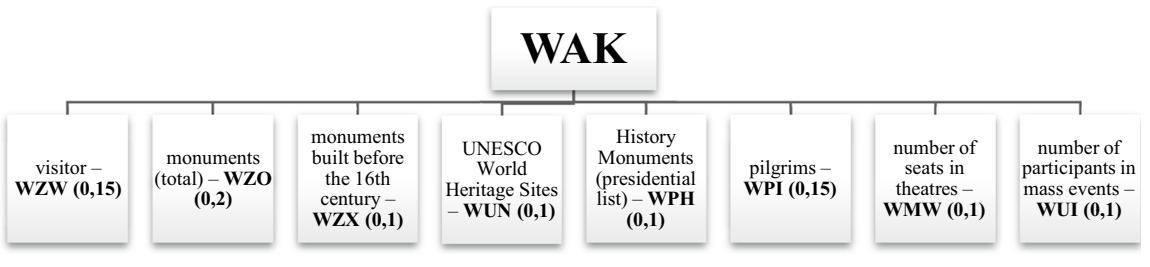

Fig. 2 Cultural attractiveness index (WAK)

where

Wsk = calculated index,

$\mathrm{W}_{\mathrm{p}}=$ variable value for a given poviat, and

$\mathrm{W}_{\max }=$ maximum variable value.

For WUN and WPH the indicator has adopted the form of

$$
W s k=100 * \frac{W_{p}}{3}
$$

where

Wsk $=$ calculated index, and

$\mathrm{W}_{\mathrm{p}}=$ variable for a given poviat assuming the value of 1,2 , or 3 , depending on the number of items in the list and their nature-a single object or group of objects (e.g.

Old Town).

The denominator is 3 , taken as the maximum variable value. $\mathrm{W}_{\mathrm{P}}$ adopts the value 1 for a single facility, 2 for an urban complex, and 3 when more than two facilities exist in the poviat.

The environmental attractiveness index (WAS) is a weighted average of five sub-indicators, in accordance with Fig. 3.

WAS is a very important index of poviat attractiveness due to the large number of protected areas in Poland and thus increased tourist traffic in these areas. Natura 2000 is a network of core breeding and resting sites for rare and threatened species, and some rare natural habitat types which are protected in their own right.

Individual sub-indicators were constructed as follows:

- Coastline length index (WLB)

$$
W L B=100 * \frac{L_{B}}{L_{\max }}
$$

where

$\mathrm{L}_{\mathrm{B}}=$ length of coastline in the poviat $(\mathrm{km})$ and

$\mathrm{L}_{\max }=$ maximum value of coastline in the poviat $(\mathrm{km})$. 


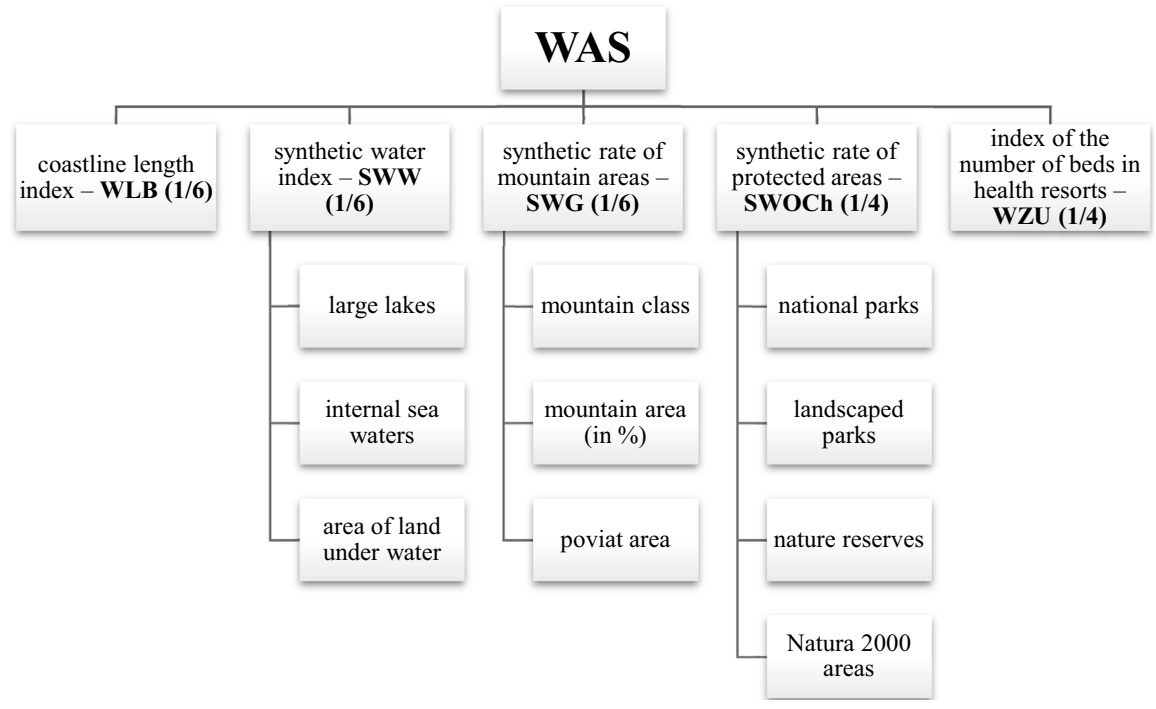

Fig. 3 Environmental attractiveness index (WAS)

- Synthetic water index (SWW)

$$
S W W=100 * \frac{\frac{J D+W M}{(J D+W M)_{\max }}+\frac{W G}{W G_{\max }}}{J D W M W G_{\max }}
$$

where

$\mathrm{JD}=$ area of large lakes $\left(\min .4 \mathrm{~km}^{2}\right)$,

$\mathrm{WM}=$ area of internal sea waters $\left(\mathrm{km}^{2}\right)$,

$(\mathrm{JD}+\mathrm{WM})_{\max }=$ maximum sum of internal sea waters and large lakes among poviats,

$\mathrm{WG}=$ area of land under water $\left(\mathrm{km}^{2}\right)$,

$\mathrm{WG}_{\max }=$ maximum value of the land area under water in poviats, and

$\mathrm{JDWMWG}_{\max }=$ maximum value of standardized surface areas: large lakes and internal sea waters and underwater soils among poviats.

- Synthetic rate of mountain areas (SWG)

$$
\begin{aligned}
S W G & =100 * \frac{I K G}{G_{\max }} \\
I K G & =\left(\sum_{i=1}^{5} K L G_{i} * \% P G_{i}\right) * P P
\end{aligned}
$$


where

$\mathrm{IKG}=$ product of mountain class,

$\mathrm{KLG}_{\mathrm{i}}=$ mountain class,

$\% \mathrm{PG}_{\mathrm{i}}=$ percentage of mountain area of a given class in the poviat,

$\mathrm{PP}=$ area of the poviat $\left(\mathrm{km}^{2}\right)$-in case of occurrence of mountain ranges of different altitude classes in the poviat, they were determined separately with differentiated values of mountain class and corresponding percentage of mountain area of a given class in the poviat, and

$\mathrm{G}_{\max }=$ maximum value of the product of mountain class.

- Synthetic rate of protected areas (SWOCh)

$$
S W O C h=100 * \frac{\left(\frac{2\left(P N_{\text {pow. }}+R P_{\text {pow. }}+P K_{\text {pow. }}\right)}{O C h_{\max }}+\frac{P N_{\text {pow. }}}{P N_{\max }}+\frac{\sum N 2000}{N 2000_{\max }}\right) \frac{1}{4}}{S W O C h N_{\max }}
$$

where

$\mathrm{PN}_{\text {pow. }}=$ area of the national park (ha),

$\mathrm{RP}_{\text {pow. }}=$ area of the nature reserve (ha),

$\mathrm{PK}_{\text {pow. }}=$ area of landscape parks (ha),

N2000 $=$ Nature 2000 area (ha),

$\mathrm{OCh}_{\max }=$ maximum value of the sum of protected areas: national parks, nature reserves, landscape parks from poviats,

$\mathrm{PN}_{\max }=$ maximum value of the area of national park from poviats (ha),

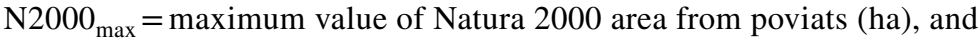

$\mathrm{SWOChN}_{\max }=$ maximum value of the synthetic index of protected areas.

- Index of the number of beds in health resorts (WZU)

$$
\mathrm{WZU}=100 * \frac{L_{B}}{L_{\max }}
$$

where

$\mathrm{L}_{\mathrm{B}}=$ beds in health resorts, and

$\mathrm{L}_{\max }=$ maximum number of beds in health resorts in poviats.

The business and hotel attractiveness index (WAB) includes the hotel accommodation index (WMN) and conference room index (WSK) (Fig. 4).

It is known that business tourism for some time has been playing an important role in overall tourism, and it is associated with the choice of hotels of a higher standard and the availability of conference rooms. Due to the lower importance of the WAB index 
Fig. 4 Business attractiveness index (WAB)

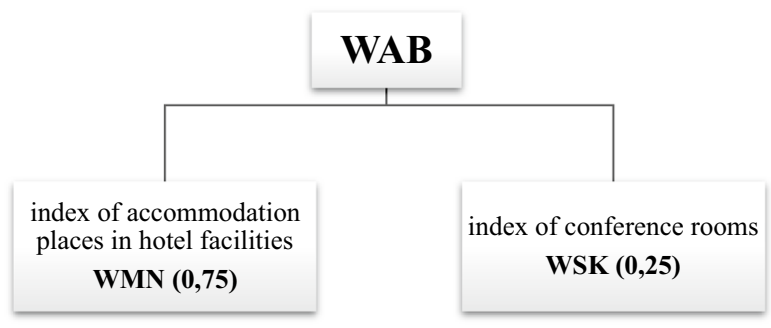

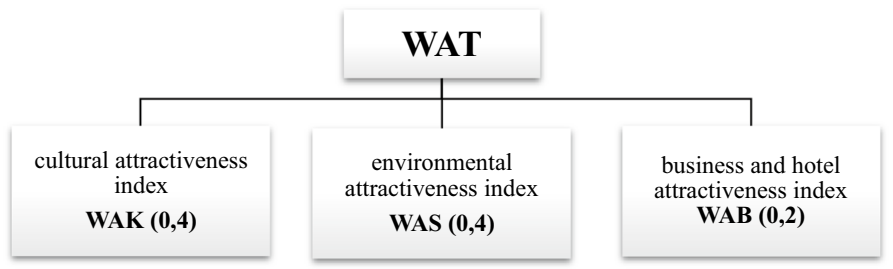

Fig. 5 Tourism attractiveness index (WAT)

compared to the first two indicators, experts have given it a weight of only 0.2 in the final, synthetic tourist attractiveness index.

The tourism attractiveness index (WAT) is weighted by the shares of WAK, WAS, and WAB (Fig. 5). ${ }^{12}$

Each index (partial and synthetic) always consists of the sum of standardized components in the range of $0-100$ and weights adding up to 1 . Standardization of components takes place by assigning the value of 100 to a poviat with maximum value and proportional conversion of values for other poviats (in this group land poviats and cities with poviat rights are treated equally) (Central Statistical Office 2017).

Comprehensive research also takes into account the impact of the neighbourhood and environment on the studied poviat. The methodology used was as follows (Central Statistical Office 2017): the basis for analysis was a set containing data on geographical coordinates and their seats. This collection was used to create a $380 \times 380$ distance matrix in which there were distances expressed in kilometres between poviats' authorities and cities with poviat rights. Administrative units were considered neighbours of a given poviat where the seat was located within a radius of $\mathrm{R}=48.564 \mathrm{~km}$ from the seat of the analysed poviat or the city with the poviat rights. This radius is three times the radius of circle $\mathrm{R}$, the area of which, multiplied by 380 (the total number of land poviats and cities with poviat rights), gives the area of Poland (Łysoń et al. 2016).

The next stage of analysis was the creation of a function describing the influence of a neighbour on a given poviat. It was assumed that with the increase in distance between the seat of a poviat and the seat of the analysed poviat, its influence will decrease. This relation is described by the following formula (Łysoń et al. 2016):

\footnotetext{
12 In world literature we can find Tourist Attractiveness Indicators (TAI). This group represents the attributes of a province that may attract tourists and covers four subcomponents: territory and environment (TAI1); infrastructure (TAI2); historical and natural attractions (TAI3); and other attractions (TAI4); this grouping principally concerns input drivers of attractiveness; see: Cugno et al. (2012) and Gismondi and Russo (2004).
} 


$$
f_{i}=1-\frac{d_{j}}{R}
$$

where

$$
\begin{aligned}
& f_{i}=\text { value of distance function for poviat } i, \\
& d_{j}=\text { distance of the seat of poviat } i \text { from the seat of poviat } j, \text { and } \\
& R=\text { assumed maximum radius. }{ }^{13}
\end{aligned}
$$

The environmental impact index on the attractiveness of a given poviat is understood as the sum of the product of the distance function and the attractiveness index $\mathrm{m}$ of neighbours located within the radius of the analysed poviat:

$$
a_{i}=\sum_{j=1}^{m} f_{j} w_{j},
$$

where

$$
\begin{aligned}
& f_{j}=\text { value of distance function for poviat } j, \text { and } \\
& w_{j}=\text { value of the attractiveness index for poviat } j .
\end{aligned}
$$

The final value of the attractiveness index for the poviat, taking into account the influence of the environment, is expressed as a weighted average:

$$
w_{i \_o}=0,75 w_{i}+0,25 a_{i},
$$

where

$w_{i \_o}=$ attractiveness index of poviat $i$, taking into account the environment,

$w_{i}=$ attractiveness index of poviat $i$, without taking into account the environment, and

$a_{i}=$ environmental impact index on poviat $i$.

Weights of $3 / 4$ and $1 / 4$ were adopted in such a way that for about $1 / 2$ of the total number of poviats and cities with poviat rights, the attractiveness component of the poviat without taking into account the environment dominates, and for the remaining $1 / 2$ - the attractiveness component with the environmental impact.

\footnotetext{
${ }^{13}$ For this purpose, the geodist function from the GMT package was used in the R environment (Magnusson 2014). Interface between the GMT map-making software and R, enabling the user to manipulate geographic data within R and call GMT commands to draw and annotate maps in postscript format. The gmt package is about interactive data analysis, rapidly visualizing subsets and summaries of geographic data, while performing statistical analysis in the R console.
} 


\section{Statistical analysis of poviats' tourist development}

\subsection{Research design and methodology}

We used the following two variables to characterize the 380 Polish poviats from the point of view of their tourism potential development: (first variable) Charvat's indicator and (second variable) density index of the accommodation facilities (see part 3). To be more precise:

first variable $=$ accommodation density, i.e. the number of hotel beds per $1 \mathrm{~km}^{2}$; and second variable $=$ tourist traffic density, i.e. the number of tourist overnight stays in hotels per 1000 inhabitants.

The authors' choice was motivated by the popularity of these two indicators across the relevant literature (Marković et al. 2017). There are obviously other variables or indicators, as mentioned earlier, but all of them and the two chosen are correlated very strongly. That is why it is sufficient to choose from the set of many available variables only two variables of different nature i.e. one relating to the supply of tourist facilities and the other describing rather the demand for them. These two variables are used in different set-ups. The first and basic set-up, characterizing the current conditions of tourism in poviats, is the one based on the values of both variables for the last year of the period investigated, i.e. for the year 2017. The second set-up, which we think may be useful in the assessment of poviats' development, concentrates on the speed or quality or rate of the development, expressed by the ratio of the value of the arithmetic mean for the last two years (2016 and 2017) and the arithmetic mean for the first two years (2010 and 2011). The speed of the development of tourist services might give more profound picture of the assessment of the whole development. Thus:

$$
\begin{aligned}
& \text { first variable }=\frac{\text { accomodation density } 2016+\text { accomodation density } 2017}{\text { accomodation density } 2010+\text { accomodation density } 2011} \\
& \text { second variable }=\frac{\text { touristtraffic density } 2016+\text { tourist traffic density } 2017}{\text { touristtraffic density } 2010+\text { tourist traffic density2 } 2011}
\end{aligned}
$$

We used the values for the first two and the last two years (instead of the first year and the last one) to lessen the effect of possible local disturbances (quotient of the sum of two values is more stable than the quotient on single values).

Our further investigation went as follows. First, to capture a general view of the current state of poviats' tourism potential, we created a scatter plot of the accommodation density and tourist traffic density for the year 2017. As it turned out from the graphical analysis (see Fig. 6) there were obvious three or four distinct clusters into which one should divide the whole set of 380 poviats, we proceeded with the analysis of the speed of poviats' development with the help of the second set-up of variables. Most of the results are presented in the form of geographical maps of Polish poviats created in Statistica software. The conclusions of our findings are presented after each figure. 


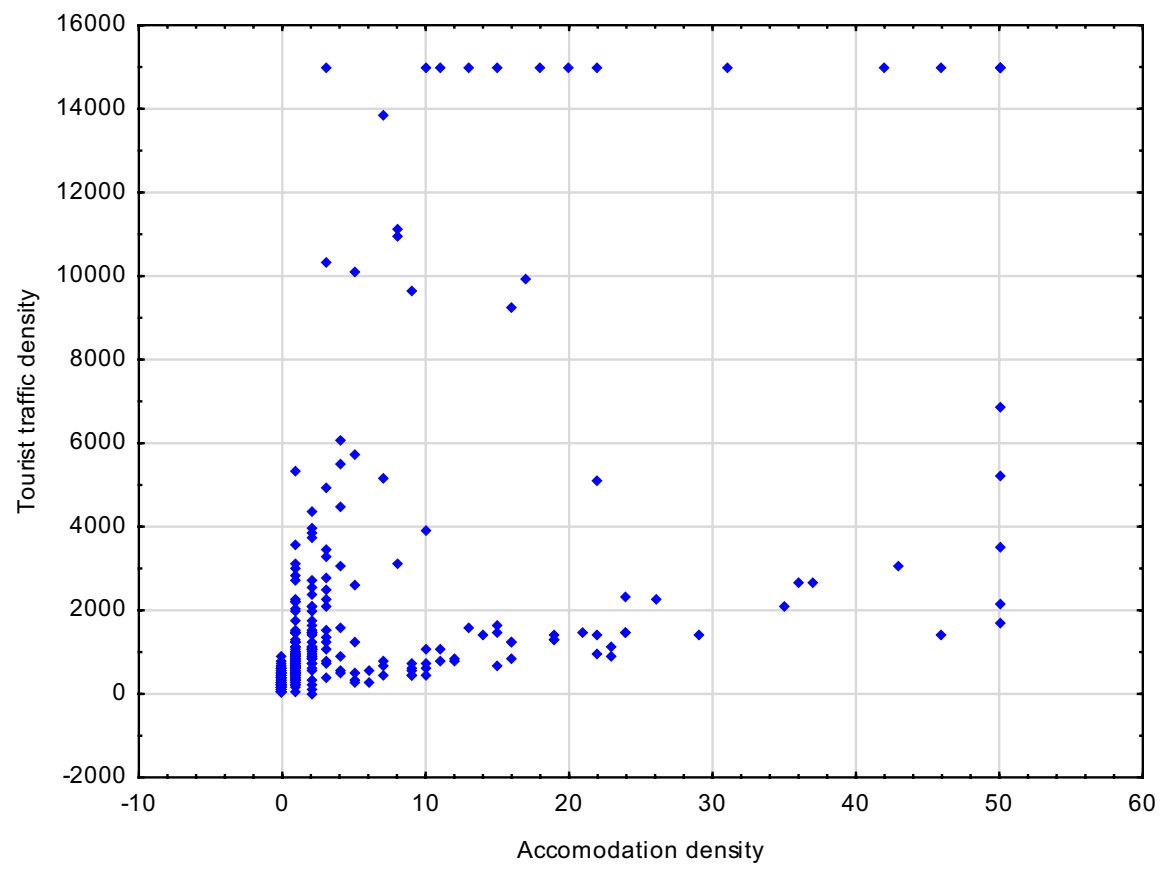

Fig. 6 Scatter plot of the truncated raw values of tourism traffic density and accommodation density. Source: Own work, data from the Local Data Bank (BDL)

\subsection{Results}

Firstly, we present an initial trial of the graphical representation of poviats' tourism potential as given by the latest values of accommodation density and tourism traffic density, i.e. for the year 2017. However, as there were a couple of poviats with extremely outlying values, we truncated (i.e. replaced the values surpassing the thresholds with the thresholds) the accommodation density at the threshold of 50 and the tourist traffic density at the threshold of 15,000. This allowed for better possibilities of examining the bulk of the data.

From Fig. 6 it follows clearly that almost all poviats have similar values of both variables or differ significantly with respect to only one of the two variables. Out of 380 , less than 10 poviats do not meet this condition. Thus, it seems reasonable to assume a threshold for each variable and to divide all poviats into four groups defined by each variable value being either below or above the threshold. As thresholds we propose to use the arithmetic mean of each variable. Thus, we will divide all 380 poviats into the following four groups:

first group-poviats with both the tourist traffic density and accommodation density below the corresponding arithmetic means;

second group-poviats with the tourist traffic density below the arithmetic mean and the accommodation density above the arithmetic mean;

third group-poviats with the tourist traffic density above the arithmetic mean and the accommodation density below the arithmetic mean; 


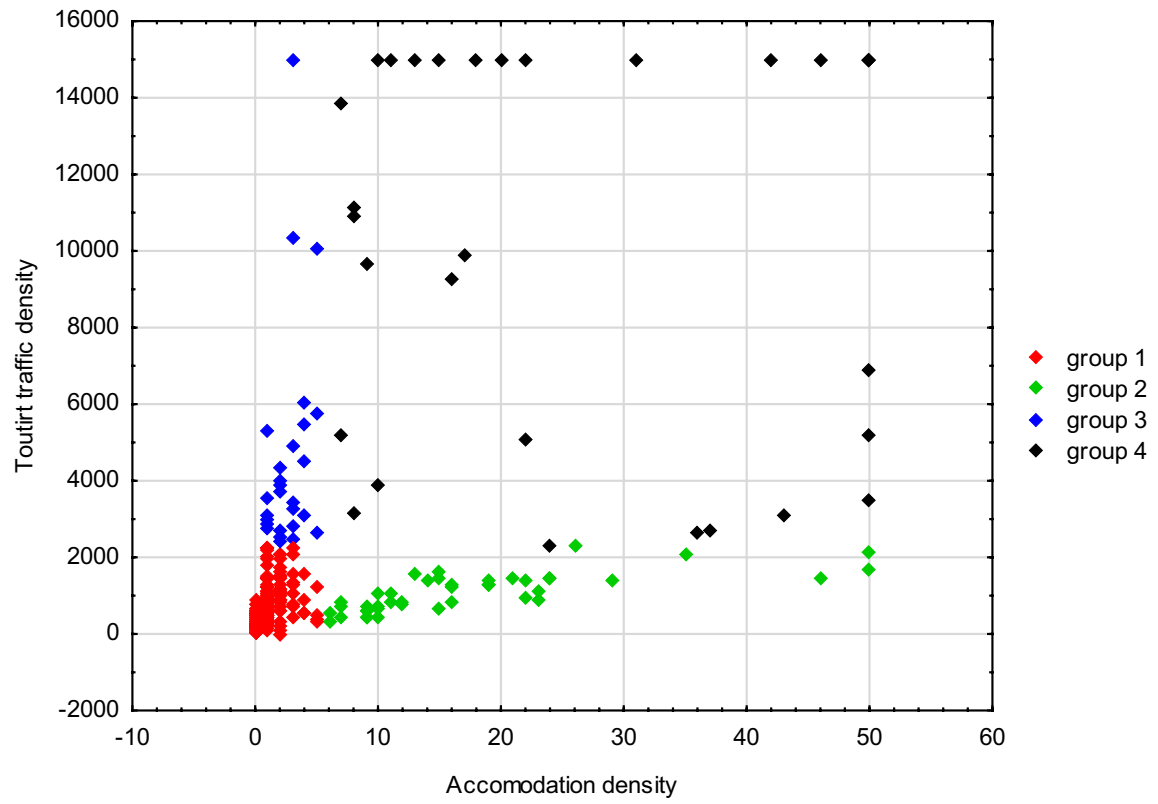

Fig. 7 Scatter plot of the truncated raw values of tourism traffic density and accommodation density with the division of poviats into four groups. Source: Own work, data from the Local Data Bank (BDL)

Fig. 8 Map of Poland by poviats. Darkest colour $=$ group 4; red colour $=$ group 1 . The light green colour represents poviats from groups 2 and 3. Source: Own work, data from the Local Data Bank (BDL). (Color figure online)

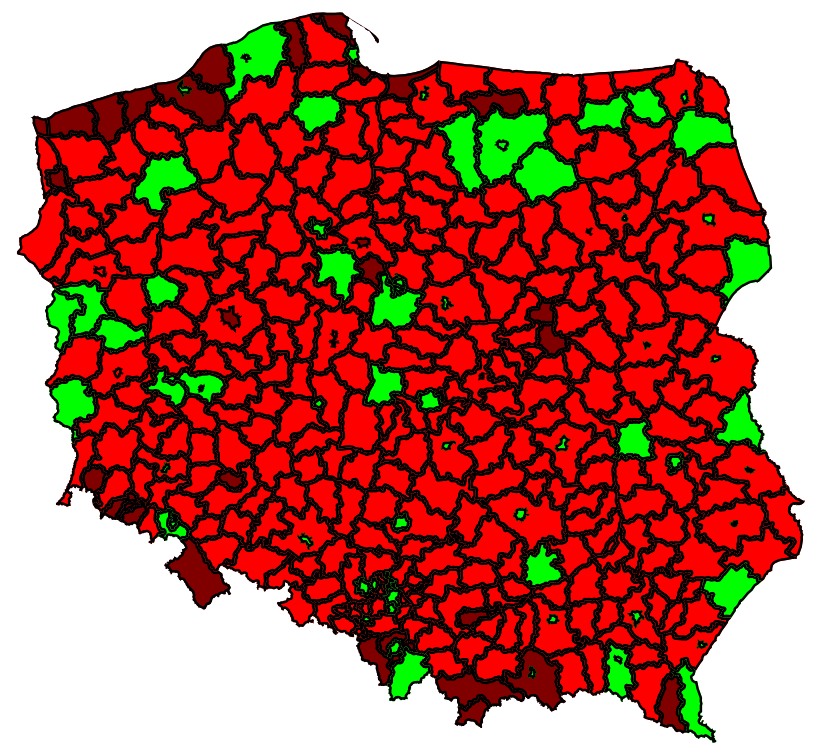

fourth group - poviats with both the tourist traffic density and accommodation density above the corresponding arithmetic means. 


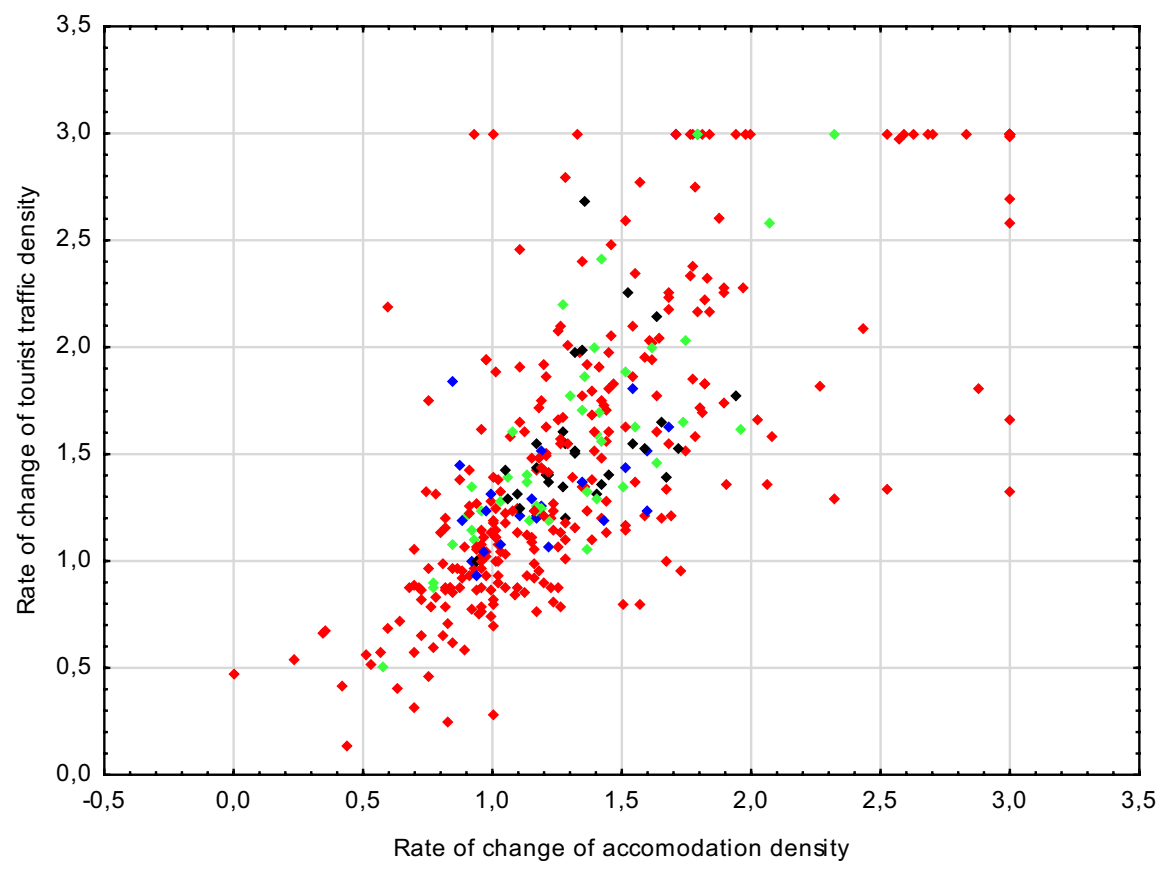

Fig. 9 Scatter plot of the rate of change of both variables with the division of poviats into four groups (group $1=$ red, group $2=$ green, group $3=$ blue, group $4=$ black). Source: Own work, data from the Local Data Bank (BDL). (Color figure online)

Graphically, the results are presented in Fig. 7. Now, it seems useful to investigate the tourist development of poviats in terms of belonging to one of the four groups, because the interpretation of this fact will be easier.

We also present in Fig. 8 the geographical positioning of what seems to us two outstanding groups: the poviats from group 1 (red colour in Fig. 7 and semi-dark colour in Fig. 8) and those from group 4 (black colour in Fig. 7 and dark colour in Fig. 8).

It is surprising that both variables have a strongly asymmetric distribution, as a vast majority of poviats (for group 1, 281 which accounts for $73.9 \%$ of all poviats) have the values of both variables below the corresponding means of both variables. The remaining three group sizes are similar. It might be interesting to observe that group 4, with both variables above the corresponding means (consisting of 30 poviats, which accounts for $7.9 \%$ of all poviats), consists of poviats situated usually in the centres of attractive tourist regions, like lake or mountain poviats. However, there are about 30 poviats also situated in attractive tourist regions (southern border of Poland, the Sudety mountains, and lake district poviats in the north of Poland) and classified in group 1. Group 2 (green colour in Fig. 7 and light green colour in Fig. 8) consists of 42 poviats (11.0\%), and group 3 (blue colour in Fig. 7 and light colour in Fig. 8) consists of 27 (7.1\%) poviats. It is also worth observing that by and large almost all poviats from groups 2, 3, and 4 lie in tourist-attractive regions of Poland. There are 6 poviats belonging to group 4 violating this rule i.e. neither from the sea border nor the mountain regions. This phenomenon may be explained if one takes into account that these poviats are old-time 
Fig. 10 Map of Poland by poviats. Darker colour $=184$ poviats developing at a faster rate than the remaining 196 marked with lighter colour. Source: Own work, data from the Local Data Bank (BDL)

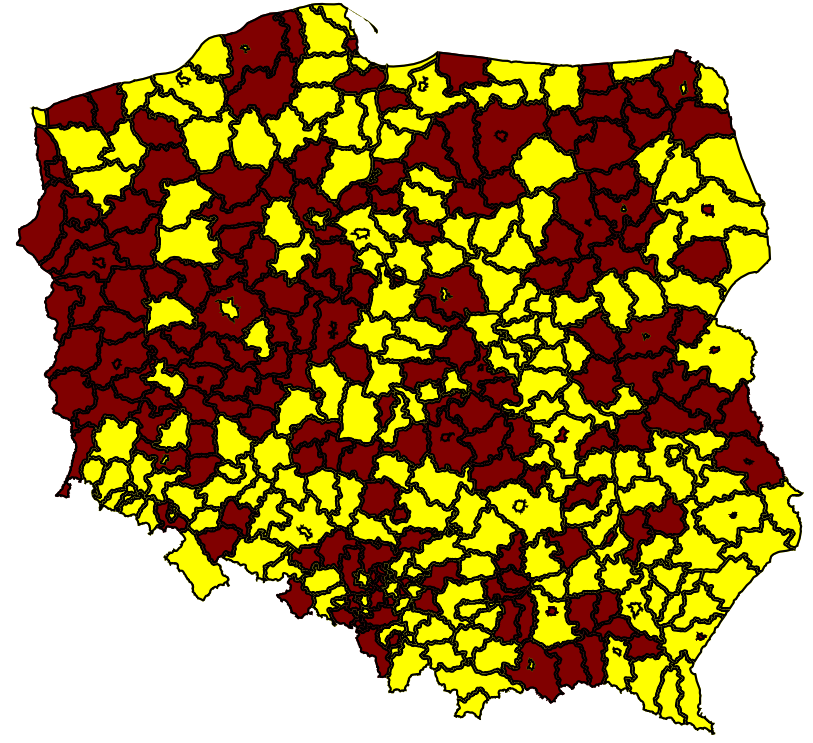

cities with rich historical background and thus, attractive for tourism (Warsaw, Poznań, Toruń, Wrocław).

As far as the assessment of the speed or quality of the tourism potential development is concerned, we present in Fig. 9 the scatter plot of the second set-up of variables, with the visible division into four groups resulting from Fig. 7.

In our opinion, it is very interesting to observe that all of the best developed poviats, i.e. those from group 4, can be found right in the middle of the plot. In our opinion this finding is quite correct, as the well-developed poviats were already developed 10 years earlier, and there was not much space for further development. In other words, these poviats earlier achieved such level of saturation that the rate of change of tourism potential could not be high. Another interesting finding from Fig. 9 is that the same observation can be made about the poviats from group 3. They also are positioned in the centre of the graph (fractionally below the poviats from group 4). Why did poviats from group 3 develop at a slow rate? We suggest the following explanation. If a poviat had tourist traffic density above average (as it is the case in group 3 poviats), then it is not easy to make it bigger, so the accommodation density which is below average does not grow. The poviats from group 2 are spread over a wider space in Fig. 9 than the poviats from groups 3 and 4 . In our opinion there is a logical explanation to this fact. If a poviat had accommodation density above average and tourist traffic density below average, then there was space for the development the latter characteristic. There is a base for such development, as the accommodation density is below average. The widest spread in Fig. 9 characterizes the poviats from group 1, i.e. those underdeveloped in both variables. How can one explain such a wide spread? In our opinion, if a poviat is underdeveloped and is situated in a tourist-attractive region, then it could be developing very fast. However, if such a poviat is situated in an unattractive region, then it might not develop at all; its tourist base might even be shrinking.

Figure 10 presents the map of Poland with the poviats divided into two groups. The group marked with dark colour represents 184 poviats developing at a faster rate than the 
remaining 196 poviats. The 184 poviats were identified as those whose Euclidean distance from the slowest developing poviat is bigger than the arithmetic mean of all the distances between every poviat and the slowest developing poviat. The number 184 , being smaller than 196, suggests that the distribution of all distances between poviats and the slowest developing poviat is slightly asymmetric; the number of poviats smaller than the arithmetic mean distance is fractionally bigger than the number of those bigger than the arithmetic mean distance.

Looking at Fig. 10, one gets two impressions. Firstly, the faster developing poviats are situated in the west and north of Poland. There is no distinct dependence on the geographical positioning i.e. we cannot claim that faster developing poviats lie in tourist-attractive regions. We interpret this result in the following way. As the general development of western regions is usually higher due to different reasons, not only of tourist nature, it is normal that in recent years these poviats were developing faster. As far as the the lack of correlation between fast development and being located in tourist-attractive regions is concerned we interpret this result so that many of the poviats from the tourist-attractive regions had already been well developed before 2008, and therefore there was no reason for their fast further development. On the other hand, the incentive for fast development was to be observed in many poviats not from the tourist-attractive regions.

To compare our findings with other research concerning tourism by poviats, we referred to the report by the Polish Central Statistical Office (Central Statistical Office 2017) and the classification of poviats with respect to their tourist attractiveness into seven classes. We divided all 380 poviats into seven classes with respect to the four variables used so far in the following way. Since, in each case, there is only one variable, it is reasonable to divide the variable range into seven segments of equal length and assign each poviat to the closest centre of a segment. We compared the classifications constructed in this way with the classification given in the Central Statistical Office (Central Statistical Office 2017). We used the Spearman rank correlation coefficient, which assumes values from interval $<-1 ; 1>$. In this kind of analysis we are confronted with tied ranks. This means that, for example, all 19 poviats of the most attractive class from page 16 (Central Statistical Office 2017, p. 16) are assigned equal rank of $(1+19) / 2=10$. We got the following results. In the first set-up of variables, the value of the coefficient was equal to 0.534 for the accommodation density and 0.550 for the tourist traffic density. In the second set-up (rate of change of both variables), the value of the coefficient was equal to 0.163 for the accommodation density and 0.191 for the tourist traffic density. Such results are quite correct in our opinion and can be interpreted as follows. The correlation of the tourist attractiveness of poviats with the rate of change of either accommodation density or tourist traffic density is very weak, which is a normal phenomenon. The attractive poviats were probably well developed before 2008 and, again as earlier, there was no reason for further development. However, the correlation between the tourist attractiveness of poviats and the state of their development in 2017 is quite high, albeit not so high as one might expect. The values fractionally bigger than 0.5 suggest that e.g. all poviats could do slightly better in developing their tourism infrastructure. However, it is impossible that all poviats present the same level of development; some do better (working for the bigger value of the coefficient) some do worse (weakening the value of the coefficient). Therefore, it should be possible to identify the poviats which lag behind in their contribution to the big positive value of the coefficient and, thus, are underdeveloped with respect to their potential. 


\section{Discussion and conclusions}

The research threads cited in this article are only a small part of the very complex nature of the issue, which is the development of tourism in the system of local government units, in this case poviats. Taking an attempt to measure the development of poviats due to their tourist values, one should be aware of some lack of precision of the concepts used (see discussion in part 3).

Certain complexity of the system, in this case constituted by the the poviats, reveals internal economic ties (and not only economic) that shape and are shaped by tourist traffic.

A given area fulfils the tourist function thanks to its diverse values, understood both as natural goods and anthropogenic goods (services). The assessment of the degree of fulfilling the tourist function of poviats, taking into account the administrative division, was carried out using various determinants, relating to the number of tourist accommodation establishments, the number of tourists using accommodations, the number of overnight stays per area, or the number of inhabitants in the area.

The analysed poviats are different in many respects. Existing areas with special natural values constitute a tourist attraction and are classified as basic tourist goods. This fact should determine their significant importance as a factor influencing the volume of tourist traffic in a given area, within which the natural environment attractions occur. However, their use for tourism and recreation purposes also depends on the existing tourist base, communication accessibility, and infrastructure. As far as the first part of the research objective is concerned, i.e. the analysis of the development of tourism in poviats, we can conclude that the simultaneous use of two most popular tourism quality determinants shows that one can distinguish four, rather homogenous groups of poviats. Each group is homogenous in the sense that all poviats from each group are very similar with respect to at least one of two variables. One group, the most numerous, comprises almost $74 \%$ of all poviats, and the poviats from this group are very similar on both variables.

As far as the second part of the research objective is concerned, the analysis carried out has shown the state of tourist development of poviats as of 2017 is considerably closely connected with their tourist attractiveness, however, it seems that there is some space for expanding natural environment advantages further.

In relation to the other research problem, whether tourism can be an opportunity for development of the poviats - the authors undertook further research. It seems also important to analyse the dependencies between the naturally valuable areas and the amount of pollution control investments and individual provinces' ability to fulfil the tourist function, which can be conducted on the basis of both correlation analysis and cluster analysis.

Open Access This article is distributed under the terms of the Creative Commons Attribution 4.0 International License (http://creativecommons.org/licenses/by/4.0/), which permits unrestricted use, distribution, and reproduction in any medium, provided you give appropriate credit to the original author(s) and the source, provide a link to the Creative Commons license, and indicate if changes were made.

\section{References}

Act on County Self-Government: Journal of Laws, No. 91, item 578, Article 4 (1998). http://prawo.sejm. gov.pl/isap.nsf/download.xsp/WDU19980910578/O/D19980578.pdf

Banasik, W.: Activities of local government for the development of tourism in Konecki poviat. p. 22 (2014) http://cejsh.icm.edu.pl/cejsh/element/bwmeta1.element.cejsh-b2d6a39d-da9d-4817-b9a8-2abcd76f14c4/c/ Dzialania_samorzadu_na_rzecz_rozwoju_turystyki_w_powiecie_koneckim.pdf. Accessed 25 Jan 2019 
Borzyszkowski, J., Marczak, M.: Organizational regulations of the County Office in Police (reproduced material). In: Tourism in the Structures of Local Government Units: Its Location and Tasks of the Relevant Entities, vol. 53. pp. 110-111, Economic Problems of Services (2010). https://www.researchga te.net/publication/323029491_Turystyka_w_strukturach_jednostek_samorzadu_terytorialnego_-_jej_ umiejscowienie_i_zadania_wlasciwych_podmiotow

Bulai, M., Cehan, A.: Tendencies in the classification and hierarchization of tourism resources. Stud. UBB Geogr. LX(1), 187-198 (2015)

Bunghez CL (2016) The importance of tourism to a destination's economy. J. East. Eur. Res. Bus. Econ. (2016). https://doi.org/10.5171/2016.143495

Butowski, L.: Tourism in the European Union's Economic and Social Cohesion Policy 1994-1999 and 2000-2006. Difin, Warsaw (2009)

Cameron, A.M., Memon, A., Simmons, D.G., Fairweather, J.R.: Evolving Role of Local Government in Promoting Sustainable Tourism Development on the West Coast, Tourism Recreation Research and Education Centre (TRREC), Report No. 28, Lincoln University (2001)

Central Statistical Office: Information note, Analysis of Tourist Values of Poviats and Their Direct Environment. Central Statistical Office, Warsaw (2017)

Chudy-Hyski, D.: Evaluation of selected conditions for development of the tourist function of the area, Infrastructure and Ecology of Rural Areas. No. 2/1/2006, Polish Academy of Science, Cracow Branch, pp. 130-131 (2006)

Creaco, S., Querini, G.: The role of tourism in sustainable economic development. Presentation at the 43rd Congress of the European Regional Science Association, 27-30 August 2003, Jyvaskyla, Finland (2003)

Cudowska-Sojko, A.: Role of tourism in the region development: theoretical aspect. Econ. Probl. Serv. 79(24), 29-30 (2011)

Cugno, M., Grimmer, M., Viassone, M.: Measuring Local Tourism Attractiveness: The Case of Italy, pp. 9-10. ANZAM, Melbourne (2012)

Dołęgowski, T.: Institutional and Systemic Competitiveness in the Global Economy, vol. 505, p. 10. ZN Warsaw School of Economics, Warsaw (2002)

Engelstoft, S., Butler, J., Smith, I., Winther, L.: Industrial clusters in Denmark: theory and empirical evidence. Pap. Reg. Sci. 85(1), 73-97 (2006)

Francis, J.: Overtourism-what is it, and how can we avoid it? (2019) https://www.responsibletrav el.com/copy/what-is-overtourism. Accessed 26 Jan 2019

Gburova, J., Matusikova, D., Benkova, E.: Perception of tourist destination brand. In: Economic Annals XXI, vol. 5-6, pp. 20-23 (2015)

Gismondi, R., Russo, M.A.: Definizione e calcolo di un indice territoriale di turisticità: un approccio statistico multivariate. Statistica LXIV(3), 549-550 (2004)

Glăvan, V.: Tourism Potential and Its Valorization (Potențialul touristic şi valorificarea sa). Ed. Fundaţiei România de Mâine, Bucharest (2006)

Godlewska, H., Typa, M.: Spatial Determinants of the Competitiveness of Enterprises, p. 7. Publishing House of the Warsaw School of Economics, Warsaw (2002)

Gołembski, G.: Setting the directions of development of tourism infrastructure. Tour. Probl. 3-4, 26-27 (1998)

Gołembski, G.: Region as a place of tourist traffic concentration. In: Gołembski, G. (ed.) Compendium of Knowledge About Tourism, p. 343. PWN, Warsaw (2009)

Hadzik, A.: Tourism of Great Sports Events in the Era of Globalization, vol. 19. WSHiU, Poznań (2010)

Hącia, E.: Analysis of the tourist function of the West Pomeranian region as a generator of transport demand. In: Cz, Christowa (ed.) Transport System of the West Pomeranian region. State Evaluation, pp. 597-598. Publishing House of the Maritime Academy, Szczecin (2010)

Hącia, E.: Conditions for the development of tourism in coastal regions in Poland. Logistic 3, 779 (2012)

Heath, E., Wall, G.: Marketing Tourism Destinations: A Strategic Planning Approach. Wiley, New York (1992)

https://www.statista.com/statistics/233223/travel-and-tourism-total-economic-contribution-worldwide/. Accessed 15 May 2019

http://www.tugberkugurlu.com/archive/definintion-of-tourism-unwto-definition-of-tourism-what-is-touri sm. Accessed 12 May 2019

Jafari, J.: Tourism models: the socio-cultural aspects. Tour. Manag. 8(2), 158 (1987)

Jakubowska, P., Kukliński, A., Żuber, P. (eds.): Issues Related to the Future of Regions. In search of a new paradigm, Ministry of Regional Development, Warsaw (2008)

Jędrzejczyk, I.: Quality as factors of building a competitive advantage on the tourist market. In: Gołembski, G. (ed.) Directions for Development of Scientific Research in Tourism, p. 27. Publishing House PWN, Warsaw (2003) 
Kruczek, P., Zmyślony, Z.: Tourist Regions. Proksenia, Cracow (2010)

Kurek, W.: Tourism. Publishing House PWN, Warsaw (2007)

Kurek, W.: Tourism, p. 410. PWN, Warsaw (2008)

Local Data Bank (BDL): https://bdl.stat.gov.pl/BDL/dane/podgrup/wymiary

Łysoń, P., Szymkowiak, M., Wawrowski, Ł.: Comparative research on tourist attractiveness of the surroundings of poviats. Wiadomości Statystyczne 12(667), 48-49 (2016)

Magnusson, A.: Interface between GMT Map-Making Software and R. R package version 2.0-1 (2014). https://cran.r-project.org/web/packages/gmt/index.html. 12 Sept 2017

Marković, S., Perić, M., Mijatov, M., Doljak, D., Žolna, M.: Application of tourist function indicators in tourism development. J. Geogr. Inst. "Jovan Cvijic” SASA 67(2), 163-178 (2017)

Matczak, A.: Recreation Function of the Suburban Zone of Łódź. Department of Urban Geography and Tourism, Łódź (1982). (unpublished)

Meyer, D.F., Meyer, N.: The role and impact of tourism on local economic development: a comparative study. Afr. J. Phys. Health Educ. Recreat. Dance (AJPHERD) 21(1:1), 197-214 (2015)

Modeste, N.C.: The impact of growth in the tourism sector on economic development: the experience of selected Caribbean countries. Econ. Int. 48, 375-385 (1995)

Nawrot, Ł., Zmyślony, P.: Tourist regions in the international competition arena: regional development programming or organized space management. Folia Turist. 21, 31-32 (2009)

Poon, A.: Tourism, Technology and Competitive Strategies, pp. 211-215. CAB International, Wallingford (1993)

Porter, M.: Regional Foundations of Competitiveness and Implications for Government Policy. Paper presented to Department of Trade and Industry Workshop (2002)

Rapacz, A. (ed.): Cooperation and Integration in Tourism in the Nysa Euroregion with a View to Membership of the European Union, p. 57. Wrocław University of Economics Publishing House, Wrocław (2004)

Richardson, R.B.: The Contribution of Tourism to Economic Growth and Food Security. USAID, Office of Economic Growth, Mali (2010)

Rocha, H.: Entrepreneurship and development: the role of clusters. Small Bus. Econ. 23, 363-400 (2004)

Rudnicki, L.: Consumer Behavior in the Tourism Market. Proksenia, Cracow (2010)

Santos Estêvão, C.M., Ferreira, J.J.: The tourism clusters role in regional development: presenting a competitiveness conceptual model. In: Conference Proceedings, Eilat, pp. 127-139 (2009)

Seweryn, R.: Tourist potential of Cracow in the field of group business meetings industry. Sci. J. Szczec. Univ. 53, 625-636 (2010)

Słodowa-Hełpa, M.: Conditions and factors for the development of tourism in the municipality (at local level). Tour. Probl. 10, 3-4 (2002)

Statista (2019). https://www.statista.com/statistics/273123/total-international-tourism-receipts/. Accessed 5 Aug 2019

Steiner, C.: Tourism, poverty reduction and the political economy: Egyptian perspectives on tourism's economic benefits in a semi-rentier state. Tour. Hosp. Plan. Dev. 3(3), 161-177 (2006)

Swizewski, C., Oancea, D.: Geography of Tourism-Part I. Geografia turismului-Partea I, Universitatea, Al. I. Cuza", Iaşi (1977)

Szromek, A.R.: Tourism Function Indexes of Tourist Reception Areas. Publishing House of the Silesian University of Technology, Gliwice (2012)

Szromek, A.R.: Measurement of the tourist function of areas by means of tourism function indexes on the example of areas of European countries. Appl. Math. Methods Econ. Manag. 132, 91-93 (2013)

Treija, S., Skujeniece, S. (eds.): Proceedings from Annual 21st Scientific Conference: Research for Rural Development. University of Agriculture (2015). Retrieved from http://www2.1lu.lv/research_conf/ Proceedings/21st_volume1.pdf. Jelgava, Latvia

Winiarski, B.: Competitiveness: selection criterion or strategy direction and indirect objective of regional policy. In: Klamut, M. (ed.) Competitiveness of Regions, pp. 9-20. Wrocław University of Economics Publishing House, Wrocław (1999)

Walton, J.K.: Tourism, Encyclopedia Britannica (2019). https://www.britannica.com/topic/tourism. Accessed 17 May 2019

WTTC: (2019). https://www.wttc.org/economic-impact/. Accessed 15 May 2019

Zalech, M.: Tourist Policy at the Local Level—Scope, Tasks, Activities, Determinants, vol. 591. Publishing House of the University of Szczecin, Szczecin (2010)

Publisher's Note Springer Nature remains neutral with regard to jurisdictional claims in published maps and institutional affiliations. 